\title{
IMPLEMENTASI KURIKULUM PENDIDIKAN AGAMA ISLAM DALAM MENINGKATKAN MUTU PENDIDIKAN DI SEKOLAH MENENGAH ATAS AL-AZHAR MEDAN
}

\author{
Derliani Daulay* \\ *Mahasiswa Program Magister FITK UIN SU
}

\begin{abstract}
This study aims to describe the learning implementation of Islamic religious education curriculum in improving the quality of education in Al-Azhar High School Medan. Include; Curriculum design, efforts to improve the quality of education, planning, implementation, and evaluation. Data collection techniques using observation, interviews. Data analysis techniques using data reduction, data display, and conclusion drawing / verification. The results of the study show that: 1) The design of the Islamic religious education curriculum that is used in Al-Azhar Medan High School is the same as the government curriculum, only there is development in the material. 2). Efforts are made in improving the quality of education by taking into account the education, output and process of education. 3) Implementation of the PAI curriculum in the presence of: planning, implementing, and evaluating education.
\end{abstract}

\section{Keywords: Curriculum Implementation, Education Quality}

\section{PENDAHULUAN}

Kurikulum sebagai aset dan indikator dalam penyelenggaraan pendidikan telah berhasil melakukan perkembangan mulai dari sentralisasi, desentralilasi sampai otonomi daerah terhadap pendidikan selalu mengalami inovasi. Kurikulum merupakan salah satu komponen pokok yang sangat menentukan dalam suatu sistem pendidikan, karena itu kurikulum bagian dari alat untuk mencapai tujuan pendidikan dan sekaligus sebagai pedoman dalam pelaksanaan proses pembelajaran pada semua jenis dan tingkat pendidikan. Tanpa kurikulum yang sesuai dan tepat akan sulit untuk mencapai tujuan dan sasaran pendidikan yang ingin di capai. Sebagaimana Nurmadiah (2014:13), menyatakan bahwa kurikulum merupakan suatu kegiatan pendidikan yang mencakup berbagai rencana kegiatan peserta didik yang terperinci berupa bentukbentuk bahan pendidikan, saran-saran strategi belajar mengajar, pengaturan-pengaturan program agar dapat diterapkan, dan hal- hal yang 
mencakup pada kegiatan yang bertujuan mencapai tujuan yang diinginkan.

Sekolah Menengah Atas Al-azhar Medan merupakan salah satu lembaga pendidikan yang berkomitmen untuk meningkatkan mutu pendidikan dengan melahirkan generasi muda yang berakhlakul karimah, unggul dalam prestasi, cemerlang dalam gagasan, menarik dalam penampilan serta tanggap terhadap perubahan dan amanah dalam bertugas dan mempunyai daya saing tinggi.

Adapun Sekolah Menengah Atas Al-azhar Medan juga memiliki ciri khas khusus yaitu menggunakan kurikulum integrasi dari dinas dan kemenag artinya sekolah ini tetap dibawah naungan dinas hanya saja mendapat izin dari kemenag untuk pengembangan kurikulum Pendidikan Agama Islam dengan mempelajari semua bidang studi PAI yang bertujuan mewujudkan visi perguruan Al-Azhar yaitu melahirkan muslim intelektual dan intelektual muslim.

Tujuan pendidikan Indonesia tertuang dalam Undang-Undang Sistem Pendidikan Nasional nomor 20 tahun 2003 pasal 3 " bahwa tujuan pendidikan nasional adalah untuk berkembangnya potensi peserta didik agar menjadi manusia yang beriman dan bertakwa pada Tuhan Yang Maha Esa, berakhlak mulia, sehat, berilmu, cakap, kreatif, mandiri, dan menjadi warga negara yang demokratis serta bertanggung jawab". Demikian juga halnya dengan kurikulum Pendidikan Agama Islam tahun 2013 yang mempunyai tujuan untuk mengembangkan kemampuan peserta didik dalam memahami, menghayati, dan mengamalkan nilainilai agama dan menyelaraskan penguasaan ilmu pengetahuan dan teknologi serta seni.

Untuk mewujudkan hal tersebut, SMA Al-Azhar Medan berupaya untuk mengembangkan kurikulum dalam menghadapi tantangan masa depan agar peserta didik dapat mempersiapkan diri dengan ilmu pengetahuan dan teknologi serta keterampilan untuk menggapai kesuksesan di masa depan. Selain faktor tersebut, aspek yang mempengaruhi kesuksesan peserta didik yang berhubungan dengan interaksi siswa dalam bermasyarakat diperlukan akhlak mulia.

Sebagaimana Bakar (2015:8) menemukan dalam penelitiannya terdapat beberapa unsur problematika Pendidikan Islam diantanya kemerosatan akhlak dan moral. Terjadinya kecendrungan kemerosotan akhlak dan moral disebabkan oleh kurangnya pendidikan nilai-nilai dalam keluarga, adanya pengaruh dari siswa lain yang menyebabkan 
rendahnya nilai dan moral siswa dalam bersikap dan bertutur kata dengan baik, serta pengaruh lingkungan masyarakat yang dapat mempengaruhi siswa dalam memilih dan mengikuti prilaku normanorma yang berlaku dalam masyarakat.

SMA Al-Azhar Medan dalam visi dan misinya yang berisikan Unggul dalam Prestasi Berdasarkan Iman dan Taqwa (Imtaq), melaksanakan pembelajaran dan bimbingan secara efektif sehingga setiap siswa berkembang secara maksimal sesuai dengan potensi yang dimiliki. Hal ini menggambarkan bahwa SMA Al-Azhar Medan berupaya meningkatkan mutu pendidikan. Selain menilai dari pengetahuan juga menilai dari aspek sikap siswa, sehingga dalam kesehariannya siswa dapat memperoleh pengetahuan dan mengaplikasikan ilmunya dalam bentuk sikap, dengan demikian akan mempengaruhi output pendidikan.

Melihat Berbagai problematika Pendidikan Agama Islam yang telah disebutkan diatas, Sekolah Menengah Atas (SMA) al-Azhar Medan hadir sebagai lembaga pendidikan yang tumbuh dan berkembang di Indonesia khususnya di Sumatera Utara. Adapun kurikulum yang digunakan di sekolah ini bermuatan kurikulum umum dari dinas pendidikan juga menggunakan kurikulum yang bermuatan agama dari kementerian agama (kemenag) yang dikembangkan oleh Lembaga Pengembangan Ilmu Agama (LPIA) al-Azhar itu sendiri. Hal yang mendasari terjadinya pengembangan kurikulum Pendidikan Agama Islam di SMA Al-Azhar Medan yaitu dengan adanya peraturan pemerintah SKB (Surat Keputusan Bersama) 3 menteri (Menteri Agama, Menteri Pendidikan dan Kebudayaan dan Menteri dalam negeri) pada tahun 1975 telah menyamakan status ataupun tarap sekolah umum dan sekolah madrasah.

Adanya peraturan pemerintah SKB 3 menteri sekolah SMA AlAzhar Medan mendapat izin dari departemen agama untuk melaksanakan pengembangan kurikulum dalam bidang studi PAI dengan mempelajari semua rumpun mata pelajaran PAI yaitu Alquran Hadist, Aqidah Akhlak, Fiqih, SKI juga dalam muatan lokal terdapat mata pelajaran Bahasa Arab. Sekolah SMA Al-Azhar ini merupak sekolah umum yang memiliki ciri khas nuansa islami, memberikan landasan Islami yang kokoh agar peserta didik memiliki kepribadian yang kuat dilandasi oleh nilai-nilai keislaman bagi perkembangan kehidupan selanjutnya. Sumber daya yang dimiliki dapat memenuhi proses pembelajaran dalam menghasilkan output yang sesuai dengan tujuan pendidikan yang bermutu. 
Mutu pendidikan merupakan kemampuan lembaga pendidikan dalam mendaya gunakan sumber-sumber pendidikan untuk meningkatkan kemampuan sistem belajar seoptimal mungkin baik dari segi pengelolaan, proses, input dan output. Mutu pendidikan saat ini menjadi kebutuhan yang sangat mendesak, persaingan lulusan pendidikan semakin ketat terutama dalam segi kualitas.

Sebagaimana Arif (2013:22), dalam penelitinnya menyimpulkan untuk mencapai mutu pendidikan harus didorong upaya peningkatan kesadaran yang terlibat dalam pengelolaan pendidikan. Selain itu, memperjelas visi, misi, pemanfaatan media elektronik, keterlibatan masayarakat, guru, siswa dan kualifikasi tenaga guru dan kegiatan dengan fasilitas yang memadai. Output yang dihasilkan harus berdasarkan suatu proses yang matang dan didukung oleh input yang baik. Kerjasama yang sinergi dalam mendukung proses penyelenggaraan harus mendapat perhatian pemerintah, dunia usaha/ industri dan semua pengelola pendidikan.

Hal yang hampir sama dengan pendapat Aziz (2015:13), dalam penelitiannya menyimpulkan bahwa, untuk mencapai pendidikan yang bermutu tidak hanya melakukan pemenuhan pada aspek input dan output saja, namun yang lebih penting adalah aspek proses. Oleh karena itu, pendidikan bermutu bukan sekedar mempersiapkan peserta didik menjadi manusia yang besar, bermakna, dan bermanfaat dizamannya, tapi juga dapat membekali peserta didik menghadap Allah SWT dialam yang teramat abadi kelak. Pendidikan Agama Islam merupakan suatu program pendidikan yang menanamkan nilai-nilai ajaran Islam, melalui proses pembelajaran, dikemas dalam mata pelajaran, yang diberi nama Pendidikan Agama Islam (PAI), baik di sekolah umum maupun sekolah di bawah naungan kementerian Agama.

Mutu pendidikan Sekolah Menengah Atas (SMA) al-Azhar Medan mempunyai potensi yang sangat besar menjadi sebuah lembaga pendidikan yang diakui kredibilitasnya dan tumbuh menjadi salah satu SMA yang banyak diminati masyarakat hal ini peneliti lihat jumlah siswa yang banyak mendaftarkan tiap tahunnya siswa, bukan hanya dari lingkungan kota Medan saja bahkan dari luar daerah dan luar provinsi Sumatera Utara dan banyak prestasi yang diraih mulai tingkat Nasional hingga Internasional dan lulusan alumni banyak yang masuk di Universitas Negeri maupun Internasional. Hal ini peneliti lihat dengan adanya disiapkan fasilitas asrama yang disediakan dari pihak yayasan, 
disiapkan untuk siswa yang berasal dari luar daerah ataupun dari luar Provinsi Sumatera Utara bisa tinggal dan menetap di asrama selama melakukan studi di perguruan al-Azhar Medan.

Sekolah Menengah Atas Al-azhar Medan merupakan salah satu lembaga pendidikan yang berkomitmen untuk meningkatkan mutu pendidikan dengan melahirkan generasi muda yang berakhlakul karimah, unggul dalam prestasi, cemerlang dalam gagasan, menarik dalam penampilan serta tanggap terhadap perubahan dan amanah dalam bertugas dan mempunyai daya saing tinggi.

Adapun Sekolah Menengah Atas Al-azhar Medan juga memiliki ciri khas khusus yaitu menggunakan kurikulum integrasi dari dinas dan kemenag artinya sekolah ini tetap dibawah naungan dinas hanya saja mendapat izin dari kemenag untuk pengembangan kurikulum Pendidikan Agama Islam dengan mempelajari semua bidang studi PAI yang bertujuan mewujudkan visi perguruan Al-Azhar yaitu melahirkan muslim intelektual dan intelektual muslim.

\section{KAJIAN TEORETIS}

Zakiah Daradjat, memandang kurikulum sebagai suatu program yang direncanakan dalam bidang pendidikan dan dilaksanakan untuk mencapai sejumlah tujuan-tujuan pendidikan tertentu (Jalaluddin dan Said 1994:43).

Pengertian kurikulum pendidikan agama Islam tidak jauh berbeda dengan kurikulum secara umum. Hanya saja yang membedakannya terletak pada mata pelajarannya. Sebagaimana Abdul Majid (2004:74) mengatakan, bahwa kurikulum Pendidikan Agama Islam adalah rumusan tentang tujuan, materi ,metode dan evaluasi pendidikan yang bersumber pada ajaran agama Islam. Dalam hal ini proses pendidikan Islam bukanlah suatu proses yang dapat dilakukan secara sembarangan, akan tetapi hendaknya mengacu kepada konseptualisasi manusia paripurna (insanul kamil) yang dalam kurikulum pendidikan Islam.

Menurut Hamalik $(2008 ; 193)$ Desain adalah suatu petunjuk yang memberi dasar, arah, tujuan dan teknik yang ditempuh dalam memulai dan melaksanakan kegiatan Hamalik Desain merupakan rancangan ataupun langkah dasar untuk memberi petunjuk arah untuk menempuh tujuan, yang terdapat didalamnnya pengembangan, proses perencanaan mencapai tujuan.selanjutnya Sukmadinata (2007:113) mendefenisikan desain kurikulum adalah menyangkut pola pengorganisasian unsur-unsur 
atau komponen kurikulum. Penyusunan desain kurikulum dapat dilihat dari dua dimensi, yaitu dimensi horizontal dan vertikal. Dimensi horizontal berkenaan dengan penyusunan dari lingkup isi kurikulum. Sedangkan dimensi vertikal menyangkut penyusunan bahan berdasarkan urutan tingkat kesukaran

Terdapat delapan Prinsip-Prinsip dalam Mendesain Kurikulum ketika akan mendesain kurikulum, prinsip-prinsip tersebut adalah sebagai berikut: (1) desain kurikulum harus memudahkan dan mendorong seleksi serta pengembangan semua jenis pengalaman belajar yang esensial bagi pencapaian prestasi belajar, sesuai dengan hasil yang diharapkan, (2) desain memuat berbagai pengalaman belajar yang bermakna dalam rangka merealisasikan tujuan-tujuan pendidikan, khususnya bagi kelompok siswa yang belajar dengan bimbingan guru; (3) desain harus memungkinkan dan menyediakan peluang bagi guru untuk menggunakan prinsip-prinsip belajar dalam memilih, membimbing, dan mengembangkan berbagai kegiatan belajar di sekolah; (4) desain harus memungkinkan guru untuk menyesuaikan pengalaman dengan kebutuhan, kapasitas, dan tingkat kematangan siswa, (5) desain harus mendorong guru mempertimbangkan berbagai pengalaman belajar anak yang diperoleh diluar sekolah dan mengaitkannya dengan kegiatan belajar di sekolah; (6) desain harus menyediakan pengalaman belajar yang berkesinambungan, agar kegiatan belajar siswa berkembang sejalan dengan pengalaman terdahulu dan terus berlanjut pada pengalaman berikutnya; (7) kurikulum harus di desain agar dapat membantu siswa mengembangkan watak, kepribadian, pengalaman, dan nilai-nilai demokrasi yang menjiwai kultur; dan (8) desain kurikulum harus realistis, layak, dan dapat diterima.Hamalik (2008: 193-194).

Kurikulum yang masih berbentuk cita-cita tersebut masih perlu dikembangkan menjadi kurikulum yang berbentuk pelaksanaan, atau sering dikenal denganactual curriculum, yakni kurikulum yang dilaksanakan oleh pendidik dalam proses belajar mengajar. Dalam menyusun atau mendesain kurikulum (dalam rangka mengembangkan kurikulum) sangatlah tergantung pada asas organisatoris, yakni bentuk penyajian atau pengimplementasian bahan pelajaran (organisasi kurikulum). Oleh karena itu, desain pengembangan kurikulum dalam pendidikan Islam diarahkan bagaimana kurikulum dirancang sesuai dengan prinsip-prinsip kurikulum perspektif Islam yang sesuai Alquran dan Hadist. 
Banyak orang yang keliru dengan pengertian "pendidikan agama Islam" dan "pendidikan Islam". Kedua istilah ini dianggap sama, sehingga ketika seseorang berbicara pendidikan Islam ternyata isinya terbatas kepada pendidikan agama Islam, atau sebaliknya ketika seseorang membicarakan pendidikan agama Islam, justru yang di bahas didalamnya adalah pendidikan Islam. Padahal kedua istilah tersebut berbeda. Sebelum menyebutkan defenisi pendidikan agama Islam terlebih dahulu Penulis sedikit membahas pengertian pendidikan Islam.

Tafsir (1995:25) membedakan antara Pendidikan Agama Islam dan Pendidikan Islam. Pendidikan Agama Islam dibakukan sebagai nama kegiatan mendidikkan agama Islam. Pendidikan Agama Islam sebagai mata pelajaran seharusnya dinamakan "Agama Islam", karena yang diajarkan adalah agama Islam, bukan Pendidikan Agama Islam. Nama kegiatannya atau usaha-usaha dalam mendidikkan agama Islam, disebut sebagai Pendidikan Agama Islam.

Pendidikan Agama Islam Menurut Muhaimin, (2014:6) Pendidikan Agama Islam merupakan salah satu bagian dari pendidikan Islam. Setiap Pendidikan Agama Islam sudah tentu pendidikan Islam, artinya pendidikan Islam lebih luas dibanding Pendidikan Agama Islam. Sementara menurut Marimba, (1989: 23) Pendidikan Agama Islam adalah bimbingan jasmani rohani berdasarkan hukum-hukum agama Islam menuju kepada terbentuknya kepribadian utama menurut ukuran-ukuran Islam. Pada hakekatnya Pendidikan Agama Islam adalah usaha orang dewasa muslim yang bertaqwa secara sadar mengarahkan dan bimbingan pertumbuhan, serta perkembangan fitrah (kemampuan dasar) anak didik melalui ajaran Islam kearah titik maksimal pertumbuhan dan perkembangan (Arifin, 1994:32).

Selanjutnya terdapat pengertian Pendidikan Agama Islam adalah pendidikan dengan melalui ajaran-ajaran agama Islam, yaitu berupa bimbingan dan asuhan terhadap anak didik agar nantinya setelah selesai dari pendidikan ia dapat memahami, menghayati dan mengamalkan ajaran-ajaran agama Islam yang telah diyakininya secara menyeluruh, serta menjadikan ajaran agama Islam sebagai suatu pandangan hidup di dunia maupun di akhirat kelak (Daradjat dan Dkk, 2008:68).

Sejalan dari defenisi Pendidikan Agama Islam diatas Tayar Yusuf mengartikan PAI adalah Usaha sadar generasi tua untuk mengalihkan pengalaman, pengetahuan, kecakapan, dan ketrampilan kepada generasi 
muda agar kelak menjadi manusia bertakwa kepada Allah SWT (Ramayulis 2005:131).

Dari beberapa pendapat diatas, maka dapat diambil kesimpulan bahwa yang dimaksud dengan Pendidikan Agama Islam adalah suatu proses kegiatan usaha orang dewasa muslim yang bertaqwa secara sadar dalam pembinaan pengalaman, pengetahuan dan keterampilan kepada generasi muda agar nantinya menjadi manusia muslil yang bertakwa kepada Allah SWT, berbudi luhur dan memiliki pribadi yang utuh dalam memahami, menghayati dan mengamalkan ajaran Islam pada kehidupan sehari-hari.

Islam sebagai agama dan Objek kajian akademik memiliki cakupan dan ruang lingkup yang luas. Secara garis besar Islam memiliki sejumlah ruang lingkup yang saling terkait yaitu: (1) lingkup keyakinan (akidah). Akidah secara bahasa (etimologi) biasa dipahami sebagai ikatan simpul dan perjanjian yang kuat dan kokoh. Ikatan dalam pengertian ini merujuk pada makna dasar bahwa manusia sejak azali telah terikat dengan satu perjanjian yang kuat untuk menerima dan mengakui adanya Sang Pencipta yang mengatur dan menguasaidirinya, yaitu Allah SWT, (2) lingkup norma (Syariat). Syariat merupakan aturan-aturan Allah yang dijadikan referensi oleh manusia dalam menata dan mengatur kehidupannya baik dalam kaitannya denga hubungan antara manusia dengan Allah SWT. hubungan antara manusia dengan Allah SWT. hubungan manusia dengan sesama manusia dan hubungan manusia dengan alam sekitarnya, dan (3) Muamalah dan perilaku (akhlak/behavior). Muamalah adalah bentukan dari akar kata „amal" yang berarti kerja. Muamalah mengandung makna keterlibatan dua orang atau lebih alam sebuah amal (kerja).

Islam sebagai agama yang komprehensif menuntut perwujudan iman dalam bentuk amal (kerja) baik dalam bentuk ritual ibadah kepada Allah SWT. maupun dalam hubungannya dengan sesama manusia bahkan dengan alam sekitarnya (Mahfud, 2010;10). Ruang lingkup materi PAI pada dasarnya mencakup tujuh unsur pokok, yaitu: (1) Al-Qur'an Hadis, (2) keimanan, (3) syariah, (4) ibadah, (5) muamalah, (6) akhlak dan (7) tarikh (sejarah Islam) yang menekankan pada perkembangan politik (Muhaimin, 2007:11).

Secara umum, tujuan pendidikan agama islam untuk membentuk peserta didik yang beriman dan bertakwa kepada Allah Swat. Berdasarkan tujuan tersebut Muhammd Nurdin ( 2014: 80 ) menjelaskan 
ada beberapa dimensi yang hendak ditingkatkan dan dituju oleh pembelajaran pendidikan agama islam, yaitu sebagai berikut :Tujuan adalah suatu yang diharapkan tercapai setelah suatu usaha atau kegiatan selesai dilakukan.

Menumbuhkan dan membina keterampilan beragama dalam semua lapangan hidup dan kehidupan serta dapat memahami dan menghayati ajaran agama Islam secara mendalam dan bersifat menyeluruh, sehingga dapat digunakan sebagai pedoman hidup, baik dalam hubungan dirinya dengan Allah SWT melalui ibadah shalat umpamanya dan dalam hubungannya dengan mausia yang tercermin dalam akhlak perbuatan serta dalam hubungan dirinya dengan alam sekitar melalui pemeliharaan dan pengolahan alam serta pemanfaatan hasil usahanya (Daradjat dan Dkk, 2008: 89-90)

Mutu adalah kemampuan yang dimiliki oleh suatu produk atau jasa yang dapat memenuhi kebutuhan atau harapan, kepuasan pelanggan yang dalam pendidikan dikelompokkan menjadi dua, yaitu internal pelanggan dan eksternal Internal pelanggan yaitu siswa atau mahasiswa sebagai pembelajar dan eksternal costumer yaitu masyarakat dan dunia industri (Fattah, 2013:2).

Mutu tidak berdiri sendiri, artinya banyak faktor untuk mencapainya dan untuk memelihara mutu. Dalam kaitan ini peran dan fungsi sistem penjamin mutu sangat dibutuhkan. Sementara itu menurut Partanto dan Dahlan (1994:505) Mutu merupakan baik buruknya sesuatu, kualitas, taraf atau derajat (kepandaian, kecerdasan) pendidikan perbuatan mendidik.

Mutu pendidikan merupakan dua istilah yang berasal dari mutu dan pendidikan, artinya menunjuk pada kualitas produk yang di hasilkan lembaga pendidikan atau sekolah. Yaitu dapat di identifikasi dari banyaknya siswa yang memiliki prestasi, baik prestasi akademik maupun yang lain,serta lulusan relevan dengan tujuan (Aan dan Cepi, 2005:5).

Menurut pengertian di atas sekolah yang dikatakan bermutu mempunyai beberapa Indikator yaitu : jumlah siswa yang banyak, hal ini menandakan antusias masyarakat terhadap lembaga pendidikan sangat tinggi. Memiliki prestasi akademi maupun non akademi. Lulusan relevan dengan lembaga pendidikan tinggi, artinya peserta didik banyak lulus di universitas negeri maupun luar negeri untuk melanjutkan ke pendidikan lebih tinggi. 
Hadis dan Nurhayati (2010:3) menjelaskan dalam persfektif makro banyak faktor yang mempengaruhi mutu pendidikan, diantaranya faktor kurikulum, kebijakan pendidikan, fasilitas pendidikan, aplikasi teknologi informasi dan komunikasi dalam dunia pendidikan, khususnya dalam kegiatan proses belajar mengajar, aplikasi metode, strategi dan pendekatan pendidikan yang mutakhir dan modern, metode evaluasi pendidikan yang tepat, biaya pendidikan yang memadai, manajement pendidikan yang dilaksanakan secara profesional, sumberdaya manusia para pelaku pendidikan yang terlatih, berpengetahuan, berpengalaman dan professional.

Mutu pendidikan merupakan dua istilah yang bersal dari kata mutu dan pendidikan, artinya menunjuk pada kualitas produk yang di hasilkan lembaga pendidikan atau sekolah (Komariah dan Tiratna 2005:5). Yaitu dapat di identifikasi dari banyaknya siswa yang memiliki prestasi, baik prestasi akademik maupun prestasi yang lain, serta lulus elevan dengan tujuan. Dikaitkan dengan pendidikan bahwa, pengertian pendidikan bermutu adalah pendidikan yang mampu melakukan proses pematangan kualitas peserta didik yang dikembangkan dengan cara membebaskan peserta didik dari ketidak tahuan, ketidak mampuan, ketidak berdayaan, ketidak benaran, ketidak jujuran dan dari buruknya akhlak dan keimanan (Mulyasana, 2011:120).

Untuk mengukur pendidikan yang berkualitas tentunya diperlukan kriteria/ indikator. Sallis (2005: 1-2) mengungkapkan ada banyak indikator mutu yang baik di lembaga pendidikan. Antara lain: 1) high moral values; 2) excellent examination results; 3) the support of parents, business and the local community; 4) plentiful resources; 5) the application of the latest technology; 6) strong and purposeful leadership; 7) the care and concern for pupils and students; 8) a well-balanced and challenging curriculum.

Pandangan ini menjelaskan bahwa sekolah yang bermutu dan baik harus meiliki: 1) nilai-nilai moral/ karakter yang tinggi; 2) hasil ujian yang sangat baik; 3) dukungan orang tua, dunia usaha dan masyarakat setempat; 4) sumber daya berlimpah; 5) implementasi teknologi terbaru; 6) kepemimpinan yang kuat dan memiliki tujuan (visi); 7) keperdulian dan perhatian bagi siswa; 8) kurikulum yang seimbang dan relevan.

Pendidikan bermutu lahir dari sistem perencanaan yang baik dengan materi dan sistem tata kelola yang baik dan disampaikan oleh guru yang baik dengan komponen pendidikan yang bermutu, khususnya 
guru. Adapun penjelasan dari materi, perencanaan, tata kelola pendidikan yang baik dan pendidikan yang bermutu sebagai berikut:

a. Materi yang baik antara lain ;1) materi yang dirasakan manfaatnya baik itu dirasakan langsung ataupun dikemudian hari oleh peserta didik. Materi yang tidak memberikan manfaat ataupun yang sudah ketinggalan zaman harusnya diperbaharui dan dikembangkan menjadi materi pelajaran yang bermanfaat; 2) materi pelajaran itu harus memberikan wawasan yang bersifat meningkat secara terus menerus; 3) memberikan pengalaman yang berharga bagi peserta didik; 4) materi yang dapat menumbuhkan semangat, motivasi, dan kreativitas berpikir bagi peserta didik; 5) materi pelajaran itu harus mampu mengubah sikap, pemikiran, dan perilaku ke arah pembentukan watak/ kepribadian yang mendorong peserta didik tampil dengan jati dirinya yang lebih matang.

b. Perencanaan pendidikan yang baik, pendidikan yang baik tidak hanya dimaksudkan untuk mempersiapkan masa depan peserta didik baik di zamannya ataupun di dunia saja, tetapi juga membekali mereka sampai menghadap Allah SWT. dengan demikian, pendidikan yang baik tidak hanya menjadikan manusia terhormat di muka bumi tetapi juga dapat memperoleh keselamatan di dunia dan kebahagian di akhirat. Hal ini sejalan dengan tujuan pendidikan nasional yang betanggung jawab untuk membentuk manusia yang beriman dan bertakwa, berakhlak mulia, cerdas,dan sebagainya.

c. Tata kelola pendidikan yang baik, adalah sistem tata kelola dengan menggunakan prinsip yang bersifat komprehensif, artinya pembangunan pendidikan bukan sekedar meningkatkan anggaran tetapi juga memperhatikan kualitas guru, budaya beajar peserta didik, kebijakan dan program serta produk dan daya dukung lingkungan. Saling terkait dan berkeseimbangan antar komponen yang satu dengan yang lainnya, serta terukur hasilnya.

d. Pendidikan yang bermutu lahir dari guru yang bermutu, guru yang bermutu paling tidak menguasai materi ajar, metodologi, sistem evaluasi, dan psikologi belajar. Guru yang baik bukan sekedar guru yang pintar tetapi guru yang bisa membuat siswa jadi pintar, guru yang mampu membentuk dan menanamkan krakter yang baik dan menjadikan siswa memiliki teladan dan patut diteladani oleh sesama. 
Guru yang baik harus mampu menciptakan proses pembelajaran yang dilakukan dengan cara-cara berikut; (1) menciptakan suasana yang mendorong para peserta didik merasa dirinya penting dan berharga, (2) menciptakan iklim belajar yang meyakinkan bahwa peserta didik mempunyai bakat dan kemampuan, (3) menciptakan iklim yang hangat dan menyenangkan, (4) mendorong tumbuhnya semangat dan motivasi berprestasi di kalangan peserta didik, (5) membentuk disiplin, tanggung jawab, dan kepercayaan diri para peserta didik, (6) membebaskan peserta didik dari ketidaktahuan dan ketidak mampuan tentang suatu konsep yang diajarkannya, (7) membebaskan peserta didik dari ketidak jujuran dan dari ketidak benaran, dan (8) mampu membebaskan siswa dari buruknya akhlak dan keimanannya (Mulyasana, 2011:123).

Terkait dengan mutu dalam Pendidikan Agama Islam tidak jau beda dalam pengertian mutu pendidikan secara umum, hanya saja ada sedikit tambahan yaitu bagaimana sekolah atau madrasah bisa menyeimbangkan antara proses dan hasil pendidikan yang pada akhirnya peserta didik menjadi manusia muslim yang berkualitas (insanul kamil). Dalam arti, peserta didik mampu mengembangkan pandangan hidup, sikap hidup dan ketrampilan hidup yang berperspektif Islam. Pehaman manusia berkualitas dalam khasanah pemikiran Islam sering disebut sebagai insan kamil yang mempunyai sifat-sifat antara lain manusia yang selaras (jasmani dan rohani, duniawi dan ukhrawi), manusia moralis (sebagai individu dan sosial), manusia nazhar dan i'tibar (kritis, berijtihad, dinamis, bersikap ilmiah dan berwawasan ke depan), serta menjadi manusia yang memakmurkan bumi (Muhaimin, 2005:201).

Adapun kriteria mutu pendidikan yang baik, sekolah diharapkan memiliki beberapa indikator yang menunjukkan bahwa sekolah tersebut sudah bisa disebut sekolah bermutu. Indikator sekolah bermutu adalah lingkungan sekolah yang aman dan tertib, sekolah memiliki tujuan dan target mutu yang ingin dicapai, sekolah memiliki kepemimpinan yang kuat, adanya pengembangan staff sekolah yang terus menerus sesuai dengan tuntutan iptek dan adanya pelaksanaan evaluasi yang terus menerus terhadap berbagai aspek akademik dan administratif serta pemanfaatan hasilnya untuk penyempurnaan atau perbaikan mutu pendidikan (Mulyasa, 2005:85). 


\section{METODOLOGI PENELITIAN}

Penelitian ini dilaksanakan sesuai dengan judul proposal ini, yaitu di Sekolah Menengah Atas Al-Azhar Medan yang beralamat di Jl. Pintu Air IV No.214 Medan, Kec. Medan Johor. Pendekatan penelitian ini menggunakan metode kualitatif. Sumber data utama (primer), diperoleh dan dikumpulkan secara langsung dari informan melalui pengamatan, catatan lapangan dan interview dari Kepala Sekolah, Guru PAI dan peserta didik Sumber data tambahan (skunder), yaitu data yang dikumpulkan, diolah, disajikan oleh pihak lain yang biasanya dari publikasi atau jurnal. Data sekunder adalah data yang sudah diolah dalam bentuk naskah tertulis atau dokumen berupa sejarah singkat sekolah atau profil sekolah, visi misi madrasah, Struktur Organisasi dan lain sebaginya. Teknik pengumpulan data terdapat empat macam teknik pengumpulan data, yaitu observasi, wawancara, dan dokumentasi. Prosedur pelaksanaan penelitian dilakukan dengan cara mereduksi data, menyajikan data dan membuat kesimpulan proses, analisis ini berlangsung selama penelitian ini berlangsung. Selanjutnyaa teknik keabsahan data adalah sebagai berikut: pengujian kredibilitas (kepercayaan), transferabilitas (keterlibatan), dependabilitas (kebergantungan), dan konfirmabilitas (kepastian) yang terkait dengan proses pengumpulan dan analisis data.

\section{HASIL PENELITIAN DAN PEMBAHASAN}

Hasil penelitian ini telah ditemukan pengembangan kurikulum dalam mencapai visi, misi dan tujuan SMA Al-Azhar Medan dalam meningkatkan mutu pendidikan. Pengembangan kurikulum harus mempunyai kemampuan kemandirian dalam meningkatkan mutu pendidikan. Tentu saja kemandirian yang dimaksud harus didukung oleh sejumlah kemampuan, yaitu kemampuan mengambil keputusan terbaik, kemampuan memajukan sumber daya, kemampuan berkomunikasi secara efektif, kemampuan memecahkan persoalan-persoalan sekolah, kemampuan adaptif dan antisipatif, kemampuan bersinergi dan berkolaborasi, dan kemampuan memenuhi kebutuhannya sendiri. Segenap kemampuan tersebut dipergunakan secara maksimal untuk melakukan perubahan menuju perbaikan. Perubahan harus dilakukan secara mandir oleh sekolah itu sendiri, karena tidak mungkin pihak luar ikut mendorong perubahan sementara pihak dalam sekolah tidak melakukannya. 
Kesiapan melakukan perubahan dengan konsep yang jelas mulai proses perencanaan, pengorganisasian, pelaksanaan, pengawasan sampai evaluasi tentu akan semakin mendekatkan pada pencapaian tujuan visi misi sekolah, termasuk peningkatan mutu yang pasti secara dinamis akan terus membutuhkan perbaikan dari waktu ke waktu. Langkah dalam mencapai mutu pendidikan melalui pengembangan kurikulum di SMA Al-Azhar Medan sebagai berikut:

\section{Desain Kurikulum PAI di SMA Al-Azhar Medan}

Desain kurikulum PAI di SMA Al-Azhar dalam meningkatkan mutu pendidikan ada beberapa tahapan:

a. Tahapan perencanaan, dalam perencanaan ditentukan apa visi, misi dan tujuan, dan terdapat penyusunan program yang akan dijalankan dalam mencapai visi, misi dan tujuan sekolah ini.

b. Tahapan pelaksanaan terdapat proses pelaksanaan yang sudah tersusun dalam prota dan prosem, RPP pada pembelajaran yang sudah disiapkan dan dikembangkan materi ajar oleh seluruh guru mata pelajarann agama (GMP) bersama ketua lembaga pengembangan ilmu agama (LPIA) yang ada di sekolah SMA AlAzhar Medan untuk menjadikan pengalaman belajar bagi peserta didik. Tahapan evaluasi, di SMA Al-Azhar terdapat evaluasi digunakan untuk mengetahui bagaimana hasil yang di peroleh peserta didik.

c. Evaluasi yang digunakan di SMA Al-Azhar adanya evaluasi harian, mid tengah semester dan ujian semester lengkap dengan ujian praktek terutaman dalam Pendidikan Agama Islam untuk mewujudkan tujuan pendidikan Nasional juga tujuan Institusional (visi dan misi SMA Al-Azhar Medan). Suatu desain kurikulum yang mengutamakan peranan siswa. Learner centered, memberi tempat utama kepada peserta didik. Di dalam pendidikan atau pengajaran yang belajar dan berkembang adalah peserta didik sendiri. Guru atau pendidik hanya berperan menciptakan situasi belajar-mengajar, mendorong dan memberikan bimbingan sesuai dengan kebutuhan peserta didik.

Hal Ini berarti bahwa kurikulum tidak hanya sebatas upaya untuk mengembangkan pendidikan, tetapi dalam upaya untuk membina peserta didik dengan segala potensi yang harus dikembangkan. SMA Al-Azhar Medan menggunakan desain kurikulum dengan model pengembangan kurikulum akademik yang biasanya terfokus pada inti ilmu pengetahuan 
yang dikelompokkan kedalam berbagai pengetahuan. Pendidikan Agama Islam terbagi ke perbidang studi yaitu Al-Qur;an Hadist, Aqidah Akhlak, Fikih, SKI. Pendidikan Agama Islam dituntun untuk berkembang baik itu melalui kurikulum ataupun perubahan yang kreatif dalam kegiatan belajar mengajar.

\section{Upaya yang Dilakukan Dalam Meningkatkan Mutu Pendidikan}

Hasil dari penelitian yang telah dilakukan upaya meningkatkan mutu pendidikan di SMA Al-Azhar medan terdapat beberapa upaya. Mulai dari visi, misi, kepala sekolah, tenaga pendidik, peserta didik, sumber daya manusia lainnya dan susana lingkungan belajar. Berbagai upaya faktor dalam peningkatan mutu pendidikan di SMA Al-Aazhar Medan diantaranya:

a. Visi, misi, berdirinya suatu lembaga pendidikan tidak terlepas dengan penetapan di awal apa visi dan misi yang akan dicapai. Sekolah SMA Al-Azhar Medan telah menetapkan visi, yaitu unggul dalam Prestasi Berdasarkan Iman dan Taqwa (Imtaq). Selain visi dari unit terdapat juga visi perguruan Al-Azhar yang harus di wujudkan yaitu: Membentuk Intelektual Muslim dan Muslim Intelektual.

1) Kepala sekolah, sebagai puncak pemimpin disekolah yang memiliki peran penting yang strategis dalam menjalankan upaya-upaya peningkatan mutu pendidikan baik itu yang berkaitan dengan input, proses, output dalam berlangsungnya pendidikan. Peran kepala sekolah sudah dijalankan dengan baik yaitu memenuhi delapan Standar Pendidikan Nasional ( SNP) sebagai berikut: 1) Standar Isi; 2) Standar Kompetensi Lulusan (SKL), 3) Standar Proses Pendidikan; 4) Standar Sarana dan Prasarana; 5) Standar Pengelolaan; 6) Standar Pembiayaan; 7) Standar Penilaian; 8) Standar Pendidik dan Tenaga Pendidik

Semua upaya-upaya yang dilakukan dalam meningkatkan mutu pendidikan di SMA Al-Azhar Medan sudah dilakukan. Untuk menjamin mutu pendidikan sudah memenuhi kedelapan Standar Nasional Pendidikan (SNP). Dengan memenuhi delapan Standar Nasional Pendidikan SMA Al-Azhar Medan terakreditasi amat baik (A ). Melihat dari hasil penelitian bahwa mutu pendidikan di SMA Al-Azhar Medan sudah meningkat dengan adanya sistem pembelajaran yang berkualitas 
dan pengembangan kurikulum Pendidikan Agama Islam serta didukung dengan tenaga pendidik yang profesional dibidang masing-masing. Segudang prestasi dari berbagai olimpiade telah diraih baik tingkat Nasional maupun Internasional. Diantanya beberapa siswa pernah mengikuti kompetisi inovasi skala Internasional dengan meraih Golden Award di Malaysia. Lomba pekan ilmiah dapat medali emas dari ratusan negara. Rutin ikut mengikuti Jambore Pramuka tingkat Internasional. Selain itu beberapa siswa juga kerap memenangkan lomba-lomba skala nasional seperti lomba film pendek sejarah, olahraga, serta kreatifitas seni lainnya. Perlombaan dalam bidang agama juga pernah memenangkan juara III Tahfidz tingkat kota Medan.

Mutu pendidikan yang meningkat di SMA Al-Azhar Medan dengan berbagai prestasi-prestasi yang diraih tidak terlepas dengan pengamalan langsung pelajaran Agama Islam, untuk belajar agama SMA Al-Azhar Medan tidak dapat diragukan lagi. Sebab sarana ibadah masjid menjadi pusat korohanian para siswa dan staf pengajar.

Kegiatan pembinaan mental dan penanaman akhlakul karimah dilakukan mulai dari pelaksanaan sholat wajib berjamah, sholat sunnah Dhuha, membiasakan membaca dan menghafal Al-Quran, malam ibadah, ramadhan center dan lainnya. Pendidikan Agama Islam merupakan skala prioritas bagi SMA Al-Azhar Medan.

Berdasarkan hasil penelitian mengenai implementasi kurikulum PAI di SMA Al-Azhar Medan sebagi berikut:

a. Perencanaan.

Perencanaan pembelajaran, diawal tahun pelajaran baru guru sudah membuat rancangan pembelajaran seperti Program tahunan, Program semester, Silabus, RPP. Dan kemudian guru diharapkan mampu mengembangkan perangkat pembelajaran ke dalam RPP.

b. Pelaksanaan.

Pelaksanaan kurikulum PAI di SMA Al-Azhar Medan sudah berjalan dengan baik dan sepenuhnya terlaksanakan karena semuanya merupakan proses yang mana harus berjalan dari awal. Dengan adanya pelatihan dan diskusi tiap bulannya yang di adakan guru PAI sangat membantu mereka dalam pelaksanan kurikulum PAI yang di kembangkan dengan materi pelajaran

c. Evaluasi.

Kegiatan evaluasi tidak terlepas dari proses pendidikan tidak akan berhenti dilakukan sepanjang proses pendidikan itu berlangsung 
sesuai jenjang pendidikan yang diikuti. Evaluasi terkait berbagai pihak, dilihat dari pihak yang berwenang melaksanakan evaluasi. Terkait evaluasi dalam implementasi kurikulum PAI juga dilakukan. Adapun evaluasi yang dilakukan di SMA Al-Azhar Medan yaitu adanya evaluasi harian, mid semester, semester. Evaluasi digunakan untuk menilai tingkat pencapaian afektif,kognitif dan psikomotorik dan tujuan SMA Al-Azhar Medan dalam jangka pendek dan jangka panjang.

\section{SIMPULAN}

Berdasarkan hasil penelitian dan pembahasan tentang implementasi kurikulum Pendidikan Agama Islam dalam meningkatkan mutu pendidikan di SMA Al-Azhar Medan dapat di ambil kesimpulan sebagai berikut:

1. Desain kurikulum pendidikan Agama Islam yang di gunakan di SMA Al-Azhar Medan yaitu sama dengan kurikulum yang dibuat oleh pemerintah baik dalam kompetensi inti maupun kompetensi dasar hanya saja dalam tema dan indikator lebih diperluas dan semua bidang studi rumpun PAI.

2. Upaya yang dilakukan dalam meningkatkan mutu pendidikan di SMA Al-Azhar Medan yaitu dengan memulai infut yang baik dalam menyiapkan visi, misi dan tujuan pendidikan. (a) Dalam Infut, dimulai dari sumber daya manusia (SDM) mulai dari rekrut guru yang profesial dibidangnya, dan juga mengadakan sleksi penjaringan siswa baru melalui test IQ, akademik dan keagamaan untuk mendapatkan sumber daya yang bermutu, (b) selanjutnya proses pembelajaran pendidikan agama Islam berperan penting dalam keseharianya dengan mengadakan pengamalan langsung ataupun praktek, menanamkan pembiasaaan bagi peserta didik yang diharapkan nantinya setelah lulus dari SMA Al-Azhar sudah tertanam dalam diri masing-masing siswa, dan (c) Output pendidikan mencapai nilai rata-rata 80 diatas KKM, lembaga pendidikan yang memiliki amanah utuk mencetak generasi yang berkompeten nantinya. Maka dalam hal ini sekolah mengupayakan dorongan-dorongan kepada semua siswa untuk berprestasi dan dapat bersaing mengikuti berbagai bidang olimpiade untuk meningkatkan prestasi siswa, serta penanaman dan pembinaan mental spiritual agar terwujud output yang yang berprestasi dan 
berakhlakul karimah. Lulus di perguruan tinggi di berbagai Universitas Negeri maupun luar Negeri melalui jalur undangan prestasi juga melalui jalur SNMPTN.

3. Implementasi kurikulum pendidikan Agama Islam dalam meningkatkan mutu pendidikan dilaksanakan pada 3 tahap mulai dari perencanaan pembelajaran, pelaksanaan dan evaluasi pembelajaran. (a). Tahap perencanaan pembelajaran guru membuat rancangan pembelajaran seperti Program tahunan, Program semester, Silabus, RPP. Dan kemudian guru diharapkan mampu mengembangkan perangkat pembelajaran ke dalam RPP, (b) Pelaksanaan, guru-guru melaksanakan pembelajaran melalui pembukaan dengan menyiapakan peserta didik untuk memulai pembelajaran, memilih metode ataupu starategi yang sesuai dengan materi pembelajaran dan menutup pelajaran dengan menyimpulkan kembali apa yang telah di pelajari, dan (3) tahap evaluasi akademik yang berjenjang mulai dari LK (Lembar kerja, UH (Ulangan Harian), Tugas, PTS (Penilaian Tengah Semester), PAS (Penilaian Akhir Semester) dan hasil dari Implementasi kurikulum pendidikan Agama Islam dalam meningkatkan mutu pendidikan dapat di lihat dari nilai siswa pada mata pelajaran tersebut yang rata-rata mencapai angka di atas KKM.

\section{REKOMENDASI}

Rekomendasi yang diberikan adalah: (1) bagi penyusun pengembang kurikulum pendidikan agama Islam yaitu lembaga pendidikan ilmu agama Al-Azhar untuk selalu memperbaharui kurikulum PAI agar selalu berkembang Bagi penyusun pengembang kurikulum pendidikan agama Islam yaitu lembaga pendidikan ilmu agama Al-Azhar untuk selalu memperbaharui kurikulum PAI agar selalu berkembang sesuai dengan zaman, (2) bagi guru-guru sekolah SMA AlAzhar Medan terkhusus guru bidang studi agama agar selalu memberikan ide-ide, masukan serta berinovasi merancang perangkat pembelajaran yang kreatif sehingga tujuan pendidikan dapat tercapai, dan (3) bagi peneliti lanjutan, diharapkan penulisan ini menjadi tambahan referensi dan masukan buat penulisan selanjutnya yang lebih baik dalam hal implementasi kurikulum Pendidikan Agama Islam dalam meningkatkan mutu pendidikan di SMA Al-Azhar Medan. 


\section{DAFTAR PUSTAKA}

Arief, Armani. (2002). Pengantar Ilmu dan Metodologi Pendidikan Islam. Jakarta: Ciputat Press.

Arifin, HM. (1991). Ilmu Pendidikan Islam. Jakarta: Bumi Aksara.

Aan dan Cepi (2005). Visonary Leadershif, Menuju sekolah Efektif. Jakarta : Bumi Aksara.

Arifin, Muzaiyyin. (2004). Filsafat Pendidikan Islam. Jakarta: Bumi Aksara.

Bakar, M. Yunus Abu. (2015). "Problematika Pendidikan Islam di Indonesia." Dirāsāt: Jurnal Manajemen dan Pendidikan Islam 1 (1): 99-123.

Daradjat, Zakiah, dan Dkk. (2008). Ilmu Pendidikan Islam. Jakarta: Bumi Aksara.

Departemen Pendidikan nasional, (2000). Manajemen Peningkatan Mutu Berbasis Sekolah. Jakarta.

Fattah, Nanang. (2013). Sistem PenjaminanMutu Pendidikan dalam Konteks Penerapan MBS. Bandung: Remaja Rosdakarya.

Idi Abdullah (2010). Pengembangan Kurikulum Teori dan Praktik.Jogjakarta : Ar_Ruzz Media,.

Jalaluddin, dan Usman said. (1994). Filsafat Pendidikan Islam. Jakarta: Raja Grafindo Persada.

Komariah, Aan, dan Cepi Tiratna. (2005). Visionary Leadershif, Menuju sekolah Efektif. Jakarta: Bumi Aksara.

Majid, Abdul, dan Dian Andayani. (2004). Pendidikan Agama Islam Berbasis Kompetensi. Bandung: Remaja Rosda Karya.

Moh. Arif. (2013). “Manajemen Madrasah Dalam Upaya Peningkatan Mutu Pendidikan Islam" Vol. 8, No. 2, (Desember).

Muhaimin. (2005). Pengembangan Kurikulum Pendidikan Agama Islam. Jakarta: Raja Grafindo Persada.

(2014). Pengembangan Kurikulum Pendidikan Agama Islam di Sekolah, Madrasah, dan Perguruan Tinggi. Cetakan Ke-6. Jakarta: Raja Grafindo Persada

Muhlison. 2015. "Peningkatan mutu Pembelajaran Pendidikan Agama Islam" 02 No.02 (Juli).

Mulyasa. 2005. Menjadi Kepala Sekolah yang Professional. Bandung: Rosda Karya.

Mulyasana, Dedy. 2011. Pendidikan Bermutu dan Berdaya Saing. Bandung: Remaja Rosdakarya. 